paragraph of description and another of general notes, could well have been modelled on Clusius.

The advertisement on the jacket says "the authors have not shirked the difficulties of technical terms and problems: they have set out to elucidate them while providing enough scientific information to give the student that essential grounding in the classification and nomenclature of plants that is necessary to him before he can proceed usefully to advanced botanical studies". It is true that there are a couple of introductory pages explaining the barest elements of classification and nomenclature: it is true that technical terms are used and are explained in the glossary (perhaps one or two illustrations of dissected flowers would have been helpful): but it is difficult to detect anything that will lead the student on to advanced botanical investigations, or which is necessary groundwork for them. No attempt has been made to include biological information on seedlings, floral functions, seed production or perennation which might entice an interested reader into the paths of botany.

Perhaps it is well to forget any idea that this is a book for potential students. Its public surely lies among those gardeners who take an intelligent interest in wild species. With Harrison's companion volume Garden Shrubs and Trees, it gives a very reasonable coverage of garden plants (excluding bulbs) in a more attractive way (and more cheaply) than the standard works of reference like the Royal Horticultural Society's Dictionary of Gardening. Its more restricted scope permits a valuable and relatively simple, yet effective, key to the genera. Another feature which enables this book to be recommended is the generally high standard of accuracy in plant names and descriptions. However, two items require comment. Under Incarvillea an unnecessary manuscript name has unfortunately been taken up (I. macrantha Grierson); the plant in question is to be called $I$. mairei (Lévl.) Grierson. In the glossary 'zygomorphic' is given a correct explanation but two inaccurate synonyms: such a flower is neither 'irregular' nor 'asymmetrical', it is bilaterally symmetrical. B. L. BuRTT

\section{DEVELOPMENTS IN PLANT ANALYSIS}

Modern Methods of Plant Analysis

Vol. V. Founded by K. Paech and M. V. Tracey, continued by H. F. Linskens and M. V. Tracey). Pp. xxvi +535 . (Berlin-Göttingen-Heidelberg: Springer-Verlag, 1962.) DM. 98.

THIS fine work is a continuation of the series Modern Methods of Plant Analysis, which is already well known to most workers on plant biochemistry and metabolism. The untimely death of Prof. K. Paech robbed the series of its initiator and co-editor, but the new editorial combination of H. F. Linskens and M. V. Tracey has maintained in this fifth volume the high standards set by the earlier parts. It is now more than seven years since the previous volumes appeared, and in the meantime there have been many developments in techniques for dealing with plant materials. The presont volume is intended to supplement and bring up to date the original Volume 1, which was concerned with analytical methods of general application. This aim has been admirably accomplished and the new volume fully justifies the description "Modern Methods".

So far as a single reviewer is able to judge, all the articles are of vory high quality. Although they are principally concernod with practical details and applications of the techniques, sufficient theoretical background is included to permit intelligent use of the methods described. The newer techniques, now widely used by workers on plant biochemistry and metabolism, are treated in full. Thus D. J. David doals with "Emission and Atomic Absorption Spectrochemical Methods", K. Biemann with "Mass Spectrometric Methods", H. Moor with "Gefriertrocknung", and B. Breyer with "Polarography and Ten- sammetry". Chromatography and allied techniques are covered by articles on "Ion-exchange Chromatography" and "Molecular Sieving other than Dirlysis" by N. K. Boardman, "Dünnschicht-Chromatographie" by E. Stahl, "Paper Chromatography on a Preparative Scale" by F. A. Hommes and H. F. Linskens, and "Vapour Phase Chromatography" by S. P. Burg. Other articles mainly concerned with macromolecules include "Determination of Size, Shape and Homogeneity of Macromolecules in Solution" by I. J. O'Donnell and E. F. Woods, "Optical Rotatory Dispersion. Its application to Protein Conformation" by E. F. Woods and I. J. O'Donnell, "Diffuse Röntgenkleinwinkelstreuung" by $\mathrm{O}$. Kratky, and "Im. munological Methods" by J. A. van der Veken, D. H. M. van Slogteren and J. P. H. van der Want. There are also more specialized articles by $\mathrm{H}$. Prat on "Méthodes Calorimétriques pour l'Analyse les Végétaux", by A. E. Dimond on "Surface Factors affecting the Penetration of Compounds into Plants" and by J. V. Possingham and P. S. Davis on "Fallout Contamination in Plants".

Two articles in particular have a considerably wider field than that of plant analysis and will be of great interest to many plant physiologists. The contribution of W. L. Butler and K. H. Norris on "Plant Spectra: Absorption and Action" deals with light-scatter phenomena, absorption spectra, action spectra and fluorescence excitation spectra. This article includes an account of the discovery and properties of phytochrome; also the role of spectra in the investigation of photosynthesis. The concise but comprehensive account by A. C. Hildebrandt on "Tissue and Single Cell Cultures of Higher Plants as a Basic Experimental Method" reveals that this technique is a useful experimental method and no longer merely a botanical curiosity.

No laboratory concerned with plant biochemistry or physiology should be without this valuable book. Although it is a German publication, many workers on both sides of the Atlantic will benefit from the fact that of the eighteen articles fourteen are written in English. As a final comment, it should be said that the volume is beßutifully printed and produced. A. Alssopr

\section{DEVELOPMENT OF HEATH SOILS}

The Development of British Heathlands and Their Soils By G. W. Dimbleby. (Oxford Forestry Memoirs, No. 23.) Pp. $120+8$ plates. (Oxford: Clarendon Press; London: Oxford University Press, 1962.) 60s. net.

ANY thousands of acres in Britain have been planted 1 with conifers by the Forestry Commission; most of these plantations are on heath soils where fertility is known to be low, yet the very existence of these trees depends on the maintenance of a minimal level of nutrients.

This Memoir investigates the development of heath soils at selected sites, chiefly in Yorkshire and in the vicinity of the New Forest, using as data soils which have been buried for varying periods by ancient earthworks. Archæological and other evidence is used to date these soils, and comparisons are made with soils of similar date from other parts of Europe. The main body of the work is followed by a substantial appendix in which detailed information on pollen spectra and soil characteristics from the 32 sites investigated form the experimental evidence for the conclusions.

In a brief discussion on methods, reference is made to a previous work by this author for the details of pollen analysis of relatively recent deposits. This is a highly controversial subject and it would not, I feel, have been out of place to have included some reference to the inherent weaknesses involved, such as the movement of pollen from one horizon to another and the variable resistance of pollen to bacterial and other action. A section on the development of soil profile indicates the various types of podzol which have been found at the different sites; the 